\title{
Governmentality and South Africa's Edifice of Gender and Sexual Rights
}

Journal of Asian and African Studies 2021, Vol. 56(I) 109-119 (C) The Author(s) 2021 Article reuse guidelines: sagepub.com/journals-permissions DOI: $10.1177 / 0021909620946854$ journals.sagepub.com/home/jas

@SAGE

\section{Desiree Lewis}

Department of Women's and Gender Studies, University of the Western Cape, South Africa

\begin{abstract}
Leading feminist scholars and activists have critiqued the current impact of South Africa's provisions for gender equality and sexual rights. The country boasts one of the most progressive constitutions in the world, and its formal mechanisms for gender transformation and sexual citizenship are - at a global level - pathbreaking. At the same time, however, violence against women, gender non-conforming people and gays and lesbians or ongoing gender-based injustices in workplaces, educational institutions and many homes testify to the fact that such measures have not transformed ideological beliefs, institutional cultures and power relations in many public and domestic contexts. This article confronts the disjuncture between the formal provision of rights and actual practice, by analysing the effects of provisions devoid of transformative impact. It is argued that the country's seemingly democratic arrangements for gender justice and sexual citizenship reproduce new forms of governmentality, biopolitics and biopower. By drawing on the work of Jasbir Puar, the article argues that South Africa's imagining as a democratic state is based largely on its provision of rights around sexuality and gender, and in relation to peripheries that are 'measured' by the absence of these. In the global imagining, gender equality and sexual citizenship currently serve as tropes for definitive freedoms and democracy. The recognition of gender equality and sexual citizenship ratifies a particular international understanding of 'democracy', one that is congruent with global neoliberal standards, and that actively reproduces the gendered, heteronormative, classist and racist status quo.
\end{abstract}

\section{Keywords}

Biopolitics, biopower, gender equality, gender mainstreaming, homonationalism, governmentality, rights, South Africa, sexual citizenship

\section{Introduction}

As Foucault (1978) has shown, governmentality under neoliberalism marks a 'benign' form of power, through the regulation of individuals as 'proper citizens'. The relationship between liberal feminism and governmentality has been explored far more extensively in the Global North than has been the case in the Global South. Feminists who have done so include Duggan (2002), writing

\section{Corresponding author:}

Desiree Lewis, Department of Women's and Gender Studies, University of the Western Cape, Private Bag XI7, Bellville 7535, South Africa.

Email: dlewis@uwc.ac.za 
about homonormativity in the United States; Eisenstein (2009), exposing how neoliberal feminism can work as a tool of US imperialism; and, more recently, Puar (2007, 2015), showing that the rights for LGBTI people in countries such as Israel and the United States bolsters the unassailable status of these countries as defensible democracies.

Puar's argument focuses on the discursive coding of citizenship, good governance and democracy, through the instrumentalising of seemingly progressive politics (see Puar, 2007, 2015). It consequently offers valuable conceptual scaffolding for understanding how a gender and sexual rights culture in South Africa works to create meanings about democracy. Puar (2007) shows that the right of LGBTI persons to the entitlements of heterosexuals in the United States marks a redefinition of the criteria for being a 'good citizen'. Many feminists and gay activists have tended to see the nation state as a defender of heteronormativity and the gender hierarchy (see McFadden, 1992: 510-520). For example, McFadden (1992: 515) has shown how feminists and 'sexual deviants' have been defined as 'troublemakers' and not properly reproductive and contributing social subjects. According to Puar (2015: 312), however, these subjects - as long as they uphold certain ideas about democratic freedoms and social progress - are embraced as productive and worthy citizens under neoliberalism. In this way, liberal feminist and LGBTI politics become organising principles in biopolitics. Certain forms of feminism and queer activism function as barometers for establishing national sovereignty, and the notion of 'democracy' entails the systematic invention of 'images of archaic time to identify what is historically new about enlightened, national progress' (McClintock, 1995: 358). Puar is concerned mainly with governmentality through 'pinkwashing' in the US and Israel. Yet her arguments can also be applied to the way South Africa (like other countries) celebrates gender equality and LGBTI rights as beacons for representing this country's democracy - as opposed to the projected 'traditionalism', 'primordialism' or inertia of others.

The measuring of democracy in South Africa through formal gender and sexual rights provisions does not, of course, invalidate the successes of feminist and LGBTI activism in this country. Struggles for sexual and gender justice from the mid-1990s to the present have been considerable. The feminist lobbying culminating in pathbreaking laws such as the Domestic Violence Act of 1998, the energies of gay and lesbian activists, which have 'successfully chiselled away at deeply patriarchal and sexist institutions' (Hames, 2008: 258) or, more recently, \#MeToo campaigns, which forced many sectors to implement policies for addressing violence and harassment, all testify to the resilience and the success of civil society activism. These struggles, however, are not the focus of this article. What I seek to reflect on is how an eviscerated edifice of 'democracy' has been mobilised by the South African government, as well as by and within a global neoliberal knowledge economy.

\section{South Africa's track record}

Feminist scholarship on the state's role in gender transformation and upholding the freedoms of LGBTI people testifies to writers' growing cynicism about legislative and policy changes. Over the years, the country's leading feminist political scientists have registered how changes promised by elaborate post-apartheid machinery, legislation and policy have given way to stasis and, in some cases, retrogression. Writing about the immediate post-apartheid period, for example, Gouws (2004) and Hassim (2003) argued that state machinery and legislation were strategically necessary, even though they expressed caution about their efficacy. In the wake of the government's Reconstruction and Development Programme and its commitment to accelerated macro-economic growth, this confidence (albeit qualified) disappeared. The declining confidence in policy activism has also been registered among feminists working within the state during the period of transition to democracy. A feminist parliamentarian, Pregs Govender, resigned in 2002 and went on six years 
later to publish a scathing exposé of the state's complicity in authoritarianism, corruption and a betrayal of the Constitution (Govender, 2008).

Current feminist views about the state's role are reflected in a pithy article for The Conversation by Amanda Gouws in 2019. Gouws (2019) writes:

The initiatives in South Africa put the country at the forefront of creating state institutions that represented the interests of women in the legislature, the executive and the state. [...] That early optimism has evaporated. While vestiges of those early initiatives remain in place [ . . ] it would be fair to say that [. . . ] the state structures did not lead to substantive representation for women. That's to say that women's presence in government has not lead [sic] to women's issues being prioritised on the political agenda.

A similar cynicism is evident in feminist analyses of sexual freedoms. Hames (2006: 1318) shows that the rights-based freedoms resulting from litigation and the passing of the Civil Union Act prioritise belonging within heterosexist society as the culmination of queer struggles for 'freedom'. And since the 'freedoms' availed by legislation coexist with persisting trends such as the rape and murder of lesbians in society, the rights-based solution to heteronormativity is as limited as the state's control over gender transformation.

The marking of 25 years since the abolition of apartheid provides a timely moment to investigate how South African 'democracy' has evolved in terms of the symbols, meanings and hegemonic discourses that now underpin global understandings of this term. It is important not only to take stock of the 'limited gains' of South Africa's efforts to achieve gender transformation and eliminate heteronormativity, but to reflect on why measures established to date have been so ineffective, and on how they actually function to reproduce aspects of the status quo. This is especially significant when we take into account the number and the scope of laws, policies and mechanisms for driving gender transformation and instituting sexual rights for all. By the start of the new millennium, South Africa had set in place pathbreaking laws, such as the Domestic Violence Act, ${ }^{2}$ the Choice on Termination of Pregnancy Act, which allows any woman or girl to obtain an abortion, and a myriad of workplace policies requiring employees to counter discrimination on the basis of gender and sexual orientation. Prior to this, its constitution was the only one in the world to highlight sexual orientation as a basis for unfair discrimination, and by 2006, the Civil Union Act allowed same-sex persons to have similar legal partnerships to those that straight people had.

One avenue for understanding why rights activism and state measures have evolved in the way they have confronts the limited implementation of policy and legislation. Here the argument has been that policies and laws have not been properly or fully translated into practice. Thus, Muthien and Combrinck (2003) argue that limited resources for ensuring that legislation such as the Domestic Violence Act is implemented actually works to undermine such legislation: an unreconstructed legal system or police force will not be able to ensure that women or sexual minorities subjected to violence achieve justice, despite the fact that the law does protect them. Those who take this position therefore do not really focus on the viability of existing laws, state machinery or policies in themselves.

An argument that does criticise 'policy activism' as having inherent limitations attributes the main problem to the state's role as a custodian and an arbiter of democratisation. In her discussion of this, Hassim (2018: 342) demonstrates how mechanisms located within the state are now cynically perceived by both right-wing and left-wing forces, since these mechanisms are 'coming under increasing attack'. She writes:

It is not only conservative forces that seek to undermine rights in the name of culture, or wealthy elites concerned about defending their rights to property through rule of law and opposing high taxation, that are 
critical. It is also challenged by radical voices that aim at creating a society free of oppression. (Hassim, 2018: 342)

According to this assessment, by the start of the new millennium the site and the drivers of gender justice and, later, sexual rights were no longer firmly lodged in civil society. Where the activism and mobilisation of LGBTI people, women, CBOs and $\mathrm{NGOs}^{3}$ had been central to driving transformation before 1994 and during the transition to democracy, the state, especially in the wake of the Reconstruction and Development Programme, came to preside over different forms of 'transformation'. As Gouws (2004: 43) argues, the state obviously comprises many actors, with 'different discursive inputs being made within different sites'. Yet the laws and policies that seem to guarantee the rights of all women, or all LGBTI people, are produced hegemonically. Different voices have uneven access to sites for litigation, redress, legal action, and even seeking justice from the law. Commenting on this in her analysis of the experiences of poor black South African women, Hames (2006: 1313-1320) argues that the rights promised by the state can never address the realities that ordinary people experience: the pursuit of gender and related freedoms has moved away from disruptive contestations about justice to top-down and mediated codifications of negotiated rights and entitlements.

In the sections that follow, I deepen this line of argument, by raising questions about democracy in relation to the state's provisions for gender and sexual rights. In the current global order, 'gender equality' and 'sexual justice' often serve as tropes of modernity and democracy. In very different ways from race, class or other markers of social difference and inequality, attitudes towards and responses to gender and sexual justice are seen as markers of progress or retrogression, as evidence either of a nation's patriarchal investment in 'tradition', or an indicator of progress and democracy. The reasons for this are complex, and they are a subject for analysis too intricate to pursue here. What should be noted for the purposes of this article's argument, however, is that sexuality and gender are now pivotally connected to how states reproduce an imagined sense of themselves in terms of linear notions of progress and qualitative ideas about freedom. The socio-economic value of heterosexuality and gendered hierarchies are central in societies whose reproduction relies on juridico-legal methods for ensuring that subjects contribute to the economy. In neoliberal contexts, especially since these are globalised, regulating principles of gender and heterosexuality lose much of their significance: in neoliberal economies, subjects' reproductive capacity is valued mainly in relation to their serviceability as economically productive agents or as viable consumers. Gender and sexuality therefore cease to have the political, economic and ideological valence that they have in other socio-economic systems.

As shown in the rest of this article, this alters the national (and often popularised) perception of non-normative sexualities and absent gender hierarchies as indicators of social 'death'. In neoliberal contexts, the salience of market-driven principles for reproducing society means that any middle-class and economically 'viable' women, gays and lesbians can be seen as productive bodies actively supporting the body politic, rather than as the body politic's outsiders. Consequently, neoliberalism draws extensively on myths invoking gender and sexuality to anchor meanings about its modernity and amenability to progress. McClintock (1995: 41) traces this to the colonial capitalist invention of a specific notion of progress, and

the invention of anachronistic space [...] as an administrative and regulatory technology in the late Victorian era. Within this trope, the agency of women, the colonized and the industrial working class are disavowed and projected onto anachronistic space: prehistoric, atavistic and irrational, inherently out of place in the historical time of modernity. 


\section{Biopolitics and gender mainstreaming}

In Foucault's explanation of governmentality, 'biopolitics' involves categorising human bodies with the aim of managing and administering social subjects (Foucault, 2010). For Foucault, biopower is a far more effective form of control by the state than juridico-legislative power, in that embodied subjects effectively manage themselves in the name of consensually established values. Whether directly or not, many radical critics of neoliberalism invoke this Foucauldian understanding to show how neoliberalism regulates subjects and establishes consensual notions about the collective good. In Puar's recent work (2015), for example, the creation of 'debility' is a productive investment for neoliberal state and civil society regulation. In contrast to the state's defence of women, gays and other marginalised groups, however, exclusion of the disabled and the maimed for the 'collective good' reveals a more overt violence. Puar's explanation of biopower therefore reveals concealed forms of state violence and oppressive subject formation under neoliberalism. Examining how the state and social subjects collude in creating certain ideas about progress and democracy can yield important insights into the complex relationships between the seemingly progressive pursuit of gender equality and state power.

This is evident in the evolution of mechanisms for transformation through 'gender mainstreaming'. Globally, gender mainstreaming became a prominent international gauge of democracy through the Beijing Platform for Action in 1995. Initially, it was rooted in progressive activism as a radical strategy for state, intersectoral and international collaboration in alleviating women's structural subordination (True and Mintrom, 2001). At one level, therefore, gender mainstreaming was defined as holistic policy implementation, institutional restructuring, educational transformation and planning for disrupting entrenched gender inequalities.

Yet the social contexts and applications of mainstreaming - both in and beyond South Africa have diluted its political focus. Describing the ameliorative impact of a 'deep structure', Joseph et al. (2011: 6) argue that '[t]he aim of gender mainstreaming is to institutionalize women's equality but through the depoliticization of gender', and that ' $[\mathrm{w}]$ here the driving force around gender activism used to be women's experiences, mainstreaming turns it into a technocratic category for redress'. The technocratic impact of mainstreaming stems partly from the way it has been linked to a Women in Development model, reaching back to the United Nations Decade for Women, which aimed to incorporate Third World women into the global economic system. The impetus behind this was not so much the needs of Third World women as it was the need of a global patriarchal system to make more women efficient contributors to a global economy.

Gender mainstreaming has been vigorously promoted alongside South Africa's neoliberal development. When the Growth, Employment and Redistribution (GEAR) macro-economic system replaced the Reconstruction and Development Programme in 1996, legislation and policy were increasingly brought in line with the idea that social progress was achievable only through maximising economic growth rates and liberalising the economy. The serviceability of gender mainstreaming to this model of progress and escalated growth is evident in the emphasis on modernisation, rational productivity and efficiency. Phrases such as 'gender equality', 'women's empowerment' and 'gender transformation' permeate mainstreaming discourses in ways that are both seductive and vacuous. It is as though rhetorical force were being substituted for any attention to actual power relations or agendas for change. Equally important in mainstreaming discourses is the reduction of social processes to technical and procedural arrangements, with these totally undermining any politically transformative potential. It is noteworthy, for example, how phrases such as 'women's empowerment', 'gender parity' or 'gender activist' are often used in policy documents or public discourses, rather than phrases that gesture towards deep changes, such as 'women's freedoms' or 'feminist transformation'. 
A look at a recent policy document, the South African National Biodiversity Institute's Gender Mainstreaming Policy of 2018, is revealing. Particularly telling is the way 'gender mainstreaming' in this document - as is the case in many other documents - becomes a trope for work efficiency and progress. The policy starts in the following way: 'Gender mainstreaming is an essential part of good governance to ensure that institutions' policies and programmes respond to the needs and interests of all employees and distribute benefits equitably between men and women' (South African National Biodiversity Institute, 2018). Also striking is how obfuscating expression actually signals a retreat from what is disruptive or what might challenge dominant patriarchal or masculinist relations and work environments. Thus, in a clause titled 'Gender-sensitive and familyfriendly policies' (South African National Biodiversity Institute, 2018), the obvious ways in which supporting the family contradict being sensitive to gendered power are entirely ignored. The rest of the clause deepens the paradoxical messages about gender:

SANBI policies must adopt language that is sensitive to gender. Where appropriate, policies should also avoid being gender-neutral, through assuming that men and women are the same. Rather, policies should recognise and equally value the similarities and differences between women and men. SANBI recognises the importance of balancing family-work life. Family responsibility leave is provided for through the SANBI leave policy. Flexi-time will be considered for parents and care-givers to carry out their family responsibilities. (South African National Biodiversity Institute, 2018) (Emphases mine)

A final significant feature of this policy that makes it typical of other similarly purposed documents or gender-mainstreaming provisions is its technical register and emphasis. The document concludes with a table for detailing quantifiable outcomes - as though work relationships and institutional cultures need only to be mechanically audited to ensure their progressiveness.

As significant as the language and the politics of policy documents such as these is how their neoliberal messages about gender equality and mainstreaming affect citizens. South Africa's gender rights edifice has increasingly cohered with a globalised ethos that promotes the individualistic and competitive pursuit of status, commodities and consumer culture. This prioritising of personal achievement and growth under capitalism is evidenced in the growing visibility of strategies for investing in young socially mobile South African women. Marked as the beneficiaries of liberal feminism, young (often black) women are offered the reward of equal and unfettered access. They are frequently construed as (and come to construe themselves as) economically enterprising actors, freed from the constraints of racial and gendered constraints, with new freedoms to compete in the aggressively neoliberal capitalist market. Ostensibly feminist messages are therefore reduced to celebrations of women as triumphant entrepreneurs and corporate leaders. ${ }^{4}$ The radical agendas and strategies of South African feminist activists and writers continue to challenge individualist and moderate calls for the empowerment of women. At the same time, the saturation of the public domain with hegemonic messages to thrive within a classed, heteronormative and patriarchal status quo stifles debate and works to confuse and erode the territory of feminist activism.

\section{Biopower and sexual citizenship}

As Mills (2018) shows, Foucault's understanding of biopower links disciplinary power to biopolitics. Biopower operates by galvanising the productive potential of both individual bodies and regional, national or global collectives. Foucault links the emergence of biopower to human bodies' regulation on the basis of sexuality (Mills, 2018: 15-17). It is the role of the sexual citizen that Puar (2007) explores in analysing homonationalism as biopower. Arguing that queer subjects, in neoliberal states, are no longer seen as unproductive or deviant citizens (a form of social 'death'), 
she shows that certain gays and lesbians are promised 'an insidious liberal one proffering an innocuous inclusion into life' (Puar, 2007: 79).

Globally, this 'life' has been critiqued by leading radical queer theorists, and many have debunked the way queer freedoms have been reduced to LGBTI people having the entitlements that straight people have. This critique includes Duggan's (2002) exploration of homonormativity and Hoad's (2007) appraisal of heterosexist institutions for same-sex subjects. But the attainment of rights for LGBTI people in South Africa has been important for a politics of recognition. Explaining this, Judge et al. (2008: 1-13) stress that the extension of legally recognised partnerships and family life for gays and lesbians has been integral to democratising South Africa in line with constitutional provisions. In so doing, they echo other queer activists and scholars who argue that, with the dismantling of discriminatory laws after 1994, all South Africans needed to be recognised as equal citizens with the power to make choices, which were previously limited to certain citizens. Struggles for recognising sexual citizenship have therefore been strategically important in the context of stateregulated homophobia under apartheid. This included the criminalising of homosexuality, through the anti-sodomy amendment to the Immorality Act in 1969, as well as the routine medicalised pathologising of queer bodies. ${ }^{5}$ In the face of the dramatic shift away from sodomy laws under apartheid to the Civil Union Act in contemporary South Africa, it is sobering to remember Puar's (2015: 319) claim that ' $[t]$ he targets and success of gay and lesbian political organising have increasingly come to be defined and measured through the prism of legalisation, leading to a palpable romance with the decriminalisation of sodomy in many national contexts'.

Heeding Puar's caution about romanticising rights, certain South African feminists and queer scholars have insisted that the right to sexual citizenship is not a universal goal for all queer bodies. Hames (2008: 263) states that 'LGBTI people may be able to achieve important rights and social acceptance within the broader heteronormative society [. . .] but by the same token they can actually validate heterosexist and patriarchal social norms [. . . This is a form of assimilation to heterosexist norms'.

Hames's critique of rights-based 'equality' also draws attention to the effects of sexual citizenship - in setting in place a construct of the properly assimilated queer subject who contributes to the dominant society by virtue of his, her or their validation of its rules. On the one hand, therefore, the struggle for the rights of LGBTI people in South Africa has had a democratising purpose; on the other hand, however, the fixation with rights - among individuals, within groups and as the state's offer of 'innocuous inclusion into life' (Puar, 2007: 79) - creates regulatory, subject-constituting and exclusionary mechanisms for rewarding good citizens and excluding others.

Biopower can be seen to operate not only within South Africa, but also relationally - in defining the sovereign South African state vis-a-vis others. As is the case with gender equality discourses, sexual citizenship rights often work to create a binary of good democracies and bad illiberal states. Good states (with the associated right to defend their sovereignty) have policies, legislation, spectacles ${ }^{6}$ and geographical spaces that mark their gay-friendly status. In fact, gay tourism in certain South African cities - which is actively supported by the national, provincial and local government - seems to be as symbolically important in this country as it is in Israel (Hartal and Sasson-Levy, 2017). Hattingh and Spencer (2020) show how prominently metropolitan cities such as Cape Town feature in the global marketing of gay tourism. Yet gay tourism, as demonstrated in many marketing images from South African gay tourist publicity material, assumes the buying power and social status of a small, gendered, raced and classed segment of the global queer population.

The promotion of South Africa's gay-friendly metropolitan cities is, of course, at odds with the realities that confront most LGBTI people in the country. Hate crimes, homophobic violence and the abuse of trans people continue to haunt many towns and cities in South Africa, and it is 
ironic that this often affects LGBTI refugees, who enter South Africa precisely because it promises them - on paper - lives of dignity and security. In practice, lives of dignity, respect and pleasure are the privilege of queer bodies whose racial, economic and gendered status entitles them to belong to the nation.

South Africa has acquired pre-eminence as a quintessential democracy also through contrast with other African states. The country is often seen as a gay haven for LGBTI people regionally, and has offered support to numerous trans, lesbian and gay activist organisations elsewhere on the continent. This has led to its being defined normatively - as a 'proper' democracy. The badge of exceptionalism has been promoted visually and in language, through a binary that inscribes certain other countries as backward, feudal and primitive. South Africa's gay-friendly image is therefore an index for measuring this country's modernity relationally. Puar (2007) shows how the orientalising of 'homophobic Arab states' pits the supposed feudalism and stasis of these countries against the contrasting modernity and dynamism of the United States. As is the case with North American homonationalism, then, South African democracy has been endlessly reimagined with reference to tropes that polarise backwardness and inertia, on the one hand, and modernity and development, on the other hand.

\section{Conclusion}

The knowledge economy is often understood to refer to the way the reproduction of the dominant global order has come to rely on the production and control of information and knowledge. It is useful to consider how knowledge under neoliberalism also determines how we make sense of our world. Metcalf (2017) appraises the sense-making language of neoliberalism as 'a language formerly confined to chalkboard simplifications describing commodity markets (competition, perfect information, rational behaviour) [that] has been applied to all of society, until it has invaded the grit of our personal lives'.

Elsewhere, I have written about how the dominance of neoliberal knowledge-making raises the challenge of understanding 'what the new forms of wielding power in our current age are', and to what extent we can 'think about radical feminist knowledge as being censored, despite the fact that it is allowed, formally, to exist' (Lewis, 2008: 93). Critically analysing the way governmentality operates also involves recognising that knowledge now enters the open market of the knowledge industry as an object of consumption, rather than as a site of and conduit in activism. In fact, Mohanty (2013: 970-972) notes that making space for radical knowledge is often fully in line with neoliberal multiculturalism. This incorporation may leave intact the structures, relationships, subjectivities and worldview that radical knowledge seeks to contest. It can also shut down crucial questions about these structures, subjectivities, relationships and assumptions. The neoliberal solution to inequalities in knowledge-making is to incorporate traditionally radical sites of knowledge through the logic of respecting difference. In this way, the solution is to make threatening legacies of knowledge available for consumption - within a pool where all schools of thought happily flourish equally. This, then, becomes the liberaldemocratic antidote to inequality.

Puar $(2007,2015)$ gives conceptual attention to assemblage, ${ }^{7}$ a term that this article has not explicitly drawn on but whose methods it enlists. Assemblage provides a valuable strategy for understanding intersecting power relations and systems that constantly shift, proliferate and cohere, either to recuperate or contest varying forms of injustice and oppression. Foregrounding assemblage rather than intersectionality as a method, Puar (2007: 213) claims that 'intersectional identities are the byproducts of attempts to still and quell the perpetual motion of assemblages, to capture and reduce them, to harness their threatening mobility'. In summarising the way assemblage avoids 
this reification yet responds to the need for theoretical alternatives, Bogic (2017: 146) writes: 'In an age of advanced capitalist globalization, the functioning logic of the world we live in today is more about folds than structures [. . . In such a nondialectical and multivocal world, we are left with an increasingly difficult task of mapping sites of power.'

This article has demonstrated that it is not possible to make political 'sense' of seemingly transformative or progressive knowledges and policies or transformational technologies in isolation from the way these are connected to economic processes, to global politics or to the forms of imperialism with which Puar $(2007,2015)$ is concerned. Puar's explanation of homonormativity may seem to be negated by the way the current president of the US is championing pro-family and anti-gay culture and laws (see Puar, 2007, 2015). Such trends suggest a resurgence of ideas about the feminist and LGBTI subject being enemies of progress and democracy in the US. And similar arguments might be made about Zuma's statecraft in South Africa. Ramaphosa's economic pragmatism is therefore presented as an antidote to Zuma-style authoritarianism, in a similar way that liberal-democratic presidential candidates might seem to offer alternatives to Trump's regression in the US. Yet Ramaphosa's role in the exercise of corporate and police power in the run-up to the Marikana massacre is a symbolic reminder of the violence that can be inflicted on social subjects by leaders and states that embrace certain democratic rights.

Like North America, South Africa continues to shore up credibility and sovereignty on the basis of global recognition of its just laws for subjects (women and queers), who are often seen as the first victims of an atavistic violence perpetuated 'elsewhere' (such as in Arab states, or in countries such as Uganda, Namibia or Zimbabwe). That the governments of these countries do often sanction homophobia or gender inequality may indeed be indisputable. At the same time, it is necessary to debunk the pathologising of the 'extreme' injustices of certain countries, and the belief that other countries (the US or South Africa) are streets ahead. Rigorous democratisation can be pursued only when changes are based on understanding the assemblage of forces, relations and configurations that link power, symbolic myth-making and social relations at the local, regional, national and global levels.

\section{Funding}

The author received no financial support for the research, authorship, and/or publication of this article.

\section{Notes}

1. Pinkwashing, a term that has become increasingly prominent in progressive queer activism and writing, refers to superficial changes to the heterosexist order to include gays and lesbians within the gendered, capitalist and racist social order.

2. Especially important about this law is that it sought to regulate conditions and relationships in the domestic sphere, which has generally been considered off limits for state intervention.

3. NGOs in particular were far closer to the political energies of civil society than is the case in the present, where NGOs are closely aligned, mainly through donor funding, with an international community significantly driven by the needs of global capitalism and its need for global 'stability'.

4. This celebration is evident, for example, in the Mail \& Guardian's annual feature of eminent young women of the year.

5. The subjection of gay white men to 'medical treatment' to make them straight was an established practice in the South African Defence Force, for example.

6. Various gay pride marches in South Africa, as is the case in other cities in countries where governments support LGBTI sexual citizenship, are significant markers of liberality and modernity.

7. Drawing on Guattari and Deleuze, Puar uses the notion of assemblage as a method in much of her influential work (see Puar, 2007, 2015). 


\section{References}

Bogic A (2017) Theory in perpetual motion and translation: Assemblage and intersectionality in feminist studies. Atlantis: Critical Studies in Gender, Culture \& Social Justice 38(1): 405-424.

Duggan L (2002) The new homonormativity: The sexual politics of neoliberalism. In: Castronovo R and Nelson DD (eds) Materializing Democracy: Toward a Revitalized Cultural Politics. Durham and London: Duke University Press, 175-194.

Eisenstein H (2009) Feminism Seduced: How Global Elites Use Women's Labor and Ideas to Exploit the World. New York: Paradigm.

Foucault M (1978) The History of Sexuality. Volume 1: An Introduction. New York: Random House.

Foucault M (2010) The Birth of Biopolitics: Lectures at the Collège de France 1978-1979. New York: Picador.

Gouws A (2004) The politics of state structures: Citizenship and the national machinery for women in South Africa. Feminist Africa (3): 27-47.

Gouws A (2019) Little is left of the feminist agenda that swept South Africa 25 years ago. The Conversation. 5 August. Available at: https://theconversation.com/little-is-left-of-the-feminist-agenda-that-sweptsouth-africa-25-years-ago-121212 (accessed 7 April 2020).

Govender P (2008) Love and Courage: A Story of Insubordination. Johannesburg: Jacana.

Hames M (2006) Rights and realities: Limits to women's rights and citizenship after 10 years of democracy in South Africa. Third World Quarterly 27(7): 1313-1327.

Hames M (2008) Lesbians and the Civil Union Act: A critical reflection. In: Judge M, Manion A and De Waal S (eds) To Have and to Hold: The Making of Same-Sex Marriage in South Africa. Johannesburg: Jacana, 258-267.

Hartal G and Sasson-Levy O (2017) Being [in] the center: Sexual citizenship and homonationalism at Tel Aviv's Gay-Center. Sexualities 20(5-6): 738-761.

Hassim S (2003) The gender pact and democratic consolidation: Institutionalizing gender equality in the South African state. Feminist Studies 29(3): 505-528.

Hassim S (2018) Decolonising equality: The radical roots of the gender equality clause in the South African constitution. South African Journal on Human Rights 34(3): 342-358.

Hattingh C and Spencer JP (2020) Homosexual not homogeneous: A motivation-based typology of gay leisure travelers holidaying in Cape Town, South Africa. Journal of Homosexuality 67(6): 768-792.

Hoad N (2007) African Intimacies: Race, Homosexuality, and Globalization. Minneapolis: University of Minnesota Press.

Joseph T, Gouws A and Parpart J (2011) A transformative approach to gender mainstreaming: Changing the deep structure of organizations. Kvinder, Køn \& Forskning (1). Available at: https://doi.org/10.7146/kkf. v0i1.28051 (accessed 7 April 2020).

Judge M, Manion A and De Waal S (2008) Introduction. In: Judge M, Manion A and De Waal S (eds) To Have and to Hold: The Making of Same-Sex Marriage in South Africa. Johannesburg: Jacana, 1-13.

Lewis D (2008) Discursive challenges for African feminisms. QUEST: An African Journal of Philosophy / Revue Africaine de Philosophie (20): 77-96.

McClintock A (1995) Imperial Leather: Race, Gender and Sexuality in the Colonial Contest. London and New York: Routledge.

McFadden P (1992) Nationalism and gender issues in South Africa. Journal of Gender Studies 1(4): 510-520.

Metcalf S (2017) Neoliberalism: The idea that swallowed the world. The Guardian. 18 August. Available at: https://www.theguardian.com/news/2017/aug/18/neoliberalism-the-idea-that-changed-the-world (accessed 7 April 2020).

Mills C (2018) Biopolitics. London and New York: Routledge.

Mohanty CT (2013) Transnational feminist crossings: On neoliberalism and radical critique. Signs: Journal of Women in Culture and Society 38(4): 967-991.

Muthien B and Combrinck H (2003) When rights are wronged: Gender-based violence and human rights in Africa. In: Bahati Kuumba M and White M (eds) Transnational Transgressions: African Women, Struggle and Transformation in Global Perspective. New York: Africa World Press, pp. 224-238. 
Puar J (2007) Terrorist Assemblages: Homonationalism in Queer Times. Durham, NC: Duke University Press. Puar J (2015) Homonationalism as assemblage: Viral travels, affective sexualities. Revita Luofona de Estudos Culturais 3(1): 319-337.

South African National Biodiversity Institute (2018) Gender Mainstreaming Policy. Available at: https:// www.sanbi.org/wp-content/uploads/2018/10/gender-mainstreaming-policy.pdf (accessed 7 April 2020).

True J and Mintrom M (2001) Transnational networks and policy diffusion: The case of gender mainstreaming. International Studies Quarterly 45(1): 27-57.

\section{Author biography}

Desiree Lewis is a Professor in the Women's and Gender Studies Department at the University of the Western Cape, South Africa. To date, her transdisciplinary research, publications and teaching have straddled South African literary and visual culture, the politics of feminist knowledge-making and activism, constructions of gender and sexualities in Africa, and representations of nationalism. She is currently focusing on food as material culture, and has published several articles on this. 